Jakub Gomułka, Mariusz Klimas, Jakub Palm

\title{
Człowiek jako wytwór siebie samego. Lem, transhumanizm i dwie koncepcje autentyczności
}

Pytanie o autentyczność jest współcześnie jedną z fundamentalnych kwestii humanistyki. Jak twierdzi Charles Taylor, nasze czasy można nazwać wiekiem autentyczności, gdyż ideał „bycia soba” stał się dzisiaj uniwersalna, przekraczająca granice klasowe wartościa społeczeństw Zachodu¹. Z kolei Michał Warchała zwraca uwagę na fakt, że nowoczesna egzystencja rozpięta jest między tęsknota za „autentycznym istnieniem” a podskórnym lękiem przed nieautentycznością i związana z nią manipulacją ${ }^{2}$. Waga pytania o autentyczność będzie zapewne wzrastać wraz z poszerzaniem się naszych możliwości kontrolowania i dostosowywania rzeczywistości do naszych potrzeb, a także przekształcania nas samych. W kontekście idei transhumanizmu pytanie to można skonkretyzować następująco: czy autoewolucja - a więc biologiczna i pozabiologiczna przemiana człowieka zgodnie z jego wyborem, a nie na skutek działania czynników pozostających poza jego kontrolą - jest szansą na większe upodmiotowienie ludzi? Czy przestając być „rzeczą” podległa ewolucji, transczłowiek stanie się w końcu kimś w pełni autentycznym?

1 Zob. Ch. Taylor, A Secular Age, Cambridge (MA) 2007, s. 474.

2 Zob. M. Warchała, Autentyczność i nowoczesność. Figury autentyczności od Rousseau do Freuda, Kraków 2006, s. 5n. 
Kwestię tę rozważać chcemy w kontekście myśli Stanisława Lema, który jest autorem pojęcia autoewolucji. Tego znanego na całym świecie polskiego autora powieści science fiction określić można jako przenikliwego proroka nadchodzacych czasów niemal całkowitej swobody manipulowania natura, której potencjał współczesnej cywilizacji technicznej jest ledwie cieniem. W swoich dalekich od optymizmu rozważaniach dotyczacych przyszłości człowieka i kultury nie stosował on pojęcia autentyczności w technicznym znaczeniu związanym z filozofią egzystencjalna, jednakże mimochodem opowiedział się - jak postaramy się wykazać - po jednej ze stron współczesnego sporu o autentyczność.

\section{Samokształtowanie człowieka jako wstęp do ewolucji technologii}

Autoewolucja jest procesem wymagającym rozwiniętej wiedzy naukowej i zaawansowanej technologii umożliwiającej co najmniej planowe przetwarzanie ludzkiego genomu bądź tworzenie doskonałych protez. Nasze obecne możliwości pozwalają na stawianie pierwszych, bardzo jeszcze niepewnych kroków na tej drodze. Na autoewolucję można jednak spojrzeć jak na część większego zjawiska samokształtowania człowieka, które, paradoksalnie, jest starsze od nauki i techniki. Zanim bowiem powstały narzędzia z kamienia, drewna czy włókna, Homo sapiens wynaleźć musiał inne, nieuchwytne narzędzia, których tworzywem było jego własne ciało. Jak wskazuje Lewis Mumford, ciało-narzędzie służyło człowiekowi pierwotnemu przede wszystkim do formowania własnej, autonomicznej względem przyrody tożsamości.

Pierwszym krokiem w tym kierunku było stworzenie języka. Zanim nauczono się korzystać z aparatu mowy, artykułując sylaby, słowa i zdania, musiano używać innych środków ekspresji. Wykonywanie ruchów, gestów, dziwnych grymasów twarzy, zwracało uwagę współplemieńców i domagało się rozumiejącej reakcji. W ten sposób - spekuluje Mumford - pierwotni ludzie ustanowili pierwsze systemy symboliczne. Nadawanie znaczenia mogło się odbywać tylko 
wewnątrz wspólnoty. Znaczące gesty i dźwięki starano się odtwarzać wielokrotnie, aż zapadły głęboko w pamięć zbiorowości i oddzieliły się od konkretnego miejsca i czasu ${ }^{3}$.

Innym polem rozwoju jaźni była aktywność rytualna - później okrzepła wokół rozróżnienia na sacrum i profanum - związana z powtarzalnymi okolicznościami przyrody takimi jak wschód słońca, nów księżyca czy cykl pór roku. Pierwsze rytuały wyrosły na czynnościach prototanecznych: spektakularna pantomima miała odzwierciedlać elementy świata - jeżeli człowiek trzepotał ramionami, był ptakiem, jeżeli grupa tworzyła miarowo wirujący krą, mogła być księżycem. Była to „technologia ciała” będąca najwcześniejszą formą ładu technicznego i najwcześniejszym przejawem znaczenia ekspresyjnego i komunikatywnego ${ }^{4}$.

Samokształtowanie człowieka polegało więc na wytwarzaniu zrębów kultury. Ustanowienie nienaruszalnego wzoru rytuału wytworzyło porządek i poczucie bezpieczeństwa, „oswajało” świat poprzez nadawanie mu znaczenia. Temu właśnie celowi miały służyć, wedle Mumforda, powtarzalne, sformalizowane czynności rytualne: gesty i odgłosy, które odzwierciedlały się i powtarzały w odgłosach i gestach bliźnich.

Na podstawie informacji uzyskanych z wykopalisk można stwierdzić, że aż do stosunkowo późnego okresu epoki kamienia człowiek nie dysponował technika pozwalająca mu skutecznie przekształcać własne środowisko. Jego pomysłowość i zdolności realizowane były głównie w sferze języka i rytuału, a własne ciało było pierwotna przestrzenią możliwych przekształceń. Mumford określił to mianem „narcyzmu technicznego”: człowiek prehistoryczny podejmował wysiłek szczególnego „ulepszania” siebie, dzięki czemu odcinał się od swojej przyrodniczej natury i mógł wyrażać swoje niezwierzęce ja. Noszenie ozdób, zabiegi kosmetyczne, malunki i tatuaże na skórze, używanie masek, przebrań, peruk, a także skaryfikacja były zwyczajami wszystkich znanych ludów pierwotnych. Praktycznie każda funkcja ciała, każda jego wydzielina budziła ciekawość i zachęcała

L. Mumford, Mit maszyny, t. I, tłum. M. Szczubiałka, Warszawa 2012, s. 94n.

4 L. Mumford, Mit maszyny, dz. cyt., s. 95-98. 
do eksperymentowania. Stosunkowo łagodnymi formami tych eksperymentów były różnorodne sposoby wykorzystania włosów: splatano, kręcono, obcinano je i doczepiano. Bardziej krwawe były proste operacje na narządach płciowych, takie jak usuwanie napletka czy przekłuwanie penisa. Ekstremalnymi przykładami manipulacji na ciele były kastracja czy trepanacja czaszki ${ }^{5}$.

Biorąc pod uwagę spostrzeżenia Mumforda można więc powiedzieć, że autoewolucja opisywana przez Lema jest zasadniczo przedłużeniem trwającego setki tysięcy lat procesu kulturowego.

\section{Lem i scenariusze autoewolucji}

Ideę autoewolucji człowieka Stanisław Lem przedstawił po raz pierwszy w swoim niebeletrystycznym opus magnum, czyli Summie technologiae (1964). Ostatni rozdział tej książki - Paszkwil na ewolucję - zawiera prognozę technologicznej ingerencji w biologiczne uposażenie gatunku Homo sapiens i stanowi rodzaj zwieńczenia koncepcji całego dzieła wyrażającego się w haśle „dogonić i przegonić Naturę".

Lem wyróżnił dwie fazy rozwoju technologicznego człowieka. Pierwsza, której wstępem jest antropogeneza, obejmuje historię i bliższą przyszłość cywilizacji. W jej trakcie dokonuje się stopniowo podporządkowywanie i przekształcanie środowiska. Apogeum tego procesu będzie inżynieria kosmiczna i technologia pozwalająca stwarzać nowe światy. Natura zostanie prześcignięta - technologia spenetruje zarówno mikro- jak i makrokosmos, a granica między tym, co naturalne a tym, co sztuczne zostanie całkowicie zatarta. Nauczymy się nie tylko doskonale wykorzystywać fundamentalne prawa przyrody, ale nawet je modyfikować. W konsekwencji tak zarysowanego procesu ostatnim reliktem Natury pozostanie człowiek ${ }^{6}$.

Druga faza rozwoju polegać będzie na przetwarzaniu samego człowieka. Moglibyśmy ją określić mianem fazy autoewolucji, jednak

5 L. Mumford, Mit maszyny, dz. cyt., s. 165-169.

6 Zob. S. Lem, Summa technologiae, Warszawa 2010, s. 311n. 
nie każda możliwa forma ingerencji technologii w naturę ludzką jest tym, co Lem określa tym terminem. Ingerencja może przybierać różne formy, które autor Summy... podzielił na trzy zasadnicze grupy. W pierwszej, konserwatywnej, nie ma jeszcze mowy o technologicznie wspomaganym samoprzekształcaniu. W jej ramach uznaje się bowiem organizm i naturalne ograniczenia człowieka za coś nienaruszalnego. Zadania biotechnologii sprowadzają się więc do usuwania chorób i ich profilaktyki, a także do wykonywania protez i transplantacji narządów. Lem nazywa takie zawężenie perspektywy biotechnologii medycznej krótkowzrocznym, a my możemy dodać, że współczesna medycyna już je przekroczyła, czego przykładem są operacje zmiany płci i chirurgia plastyczna - obie opierają się na założeniu, że naturę można, a czasem nawet trzeba, poprawiać.

Druga forma ingerencji techniki w ciało jest bardziej radykalna. Przekracza ona cele pierwszej z opisanych form, poszerzając je o działania regulacyjne prowadzone na kodzie genetycznym. Działania te moga być podejmowane bądź w celu neutralizacji negatywnych konsekwencji zaniku selekcji naturalnej, bądź też eliminacji pewnych niedoskonałości i ograniczeń ludzkiego ciała. Tu mamy już do czynienia z autoewolucja - konsekwencją tego rodzaju przekształceń będzie bowiem wytworzenie - w perspektywie setek, a nawet tysięcy lat - „nowego modelu Homo sapiens”.

Trzecia $\mathrm{z}$ form ingerencji technologii jest najbardziej radykalna. W jej ramach odrzucone zostana - jako niewystarczające - ramowe ograniczenia wypracowane na drodze bioewolucji. Zamiast stopniowo modyfikować kod genetyczny dokonamy całkowitego przeprojektowania istoty rozumnej, począwszy od zmiany jej „budulca” na bardziej trwały niż struktury białkowe ${ }^{7}$. Śmiałość tej ostatniej koncepcji wydaje się (bądź raczej wydawała w latach 60.) wręcz absurdalna, jednak Lem wskazuje, że prowadzi do niej nieuchronnie powszechne dążenie do perfekcji i efektywności.

Już tu jednak pojawia się wątek krytyki autoewolucji wskazujący na rolę ciała w kształtowaniu kultury. Umysł ludzki jest wcielony,

7 Zob. S. Lem, Summa technologiae, dz. cyt., s. 312n. 
a zatem rezygnacja z jego biologicznych uwarunkowań zagrozi całości kultury i sztuki.

Cielesność ukształtowała kanony wszystkich historycznych estetyk, wszystkie istniejące języki, a przez to i całość myślenia ludzkiego. Cielesny jest przecież nasz duch; nieprzypadkowo to słowo wywodzi się z oddychania. Wbrew pozorom nie ma też wartości, które powstałyby bez udziału czynnika cielesnego. [...] Gdyby człowiek naprawdę miał sam siebie przekształcić pod naciskiem wytworzonych własnymi rękoma technologii, gdyby miał za swego następcę uznać robota z doskonałym mózgiem krystalicznym, byłoby to największym jego szaleństwem. Oznaczałoby to ni mniej, ni więcej, jak tylko fakt zbiorowego samobójstwa rasy $[\ldots]^{8}$.

Autor nie pozostawia wszakże tych zarzutów bez odpowiedzi. Wcielając się w zwolennika wizji radykalnej przebudowy człowieka, stwierdza, że nie wszystkie rozwiazania powstałe w toku ewolucji zasługuja na zachowanie. Podkreśla przede wszystkim „niefortunność” częściowego zespolenia dróg płciowych i wydalniczych - według Lema miało to negatywny wpływ na kształtowanie się systemów religijnych, w których seksualność wiąże się zwykle z czymś nieczystym i dwuznacznym ${ }^{9}$. Ponadto punktuje inne wady „konstrukcyjne” obecnej formy ciała człowieka, wykazujac, że nie jest ona w pełni dostosowana ani do przyjętej jeszcze przez naszych ewolucyjnych przodków postawy wyprostowanej, ani do rozrostu mózgoczaszki. Co najważniejsze jednak, dyskredytuje postawę krytyczną wobec radykalnego programu autoewolucji jako irracjonalna. Jej podstawowym oparciem nie sa bowiem chłodne argumenty, lecz emocje: przywiązanie do systemów wartości zakorzenionych w ciele i jego ułomnościach oraz lęk przed całkowitym zaprzepaszczeniem duchowej spuścizny człowieka; jego ulepszony następca nie będzie podzielał

8 Zob. S. Lem, Summa technologiae, dz. cyt., s. 315.

9 Watek ten kilkakrotnie powraca w prozie i eseistyce Lema, najbardziej rozbudowany jest w powieści Wizja lokalna (zob. S. Lem, Wizja lokalna, Kraków-Wrocław 1983). 
z nim podstawowych egzystencjalnych niepokojów, trudno zatem oczekiwać, że będzie zachwycał się arcydziełami literatury i sztuki, które na nich wyrosły.

Znakomitą ilustracją tej nakreślonej pół wieku temu przez Lema postawy krytycznej może być współczesne stanowisko Francisa Fukuyamy, amerykańskiego politologa, filozofa i ekonomisty, zaprezentowane w książce Koniec człowieka. Konsekwencje rewolucji biotechnologicznej (2002). Swoje obawy autor ten koncentruje między innymi na możliwości wyzbycia się przez ludzi emocji, cierpienia i bólu - to właśnie one, a nie rozum, którego rolę akcentują transhumaniści, otwarcie odwołując się do dziedzictwa Oświecenia, miałyby stanowić o istocie człowieczeństwa. Tę ostatnią Fukuyama utożsamia z wypracowaną przez ewolucję biologiczna spuścizna genetyczna gatunku, do pewnego stopnia uzupełniona przez ewolucję kulturowa. Urzeczywistnienie wizji transhumanistów, a więc radykalnej autoewolucji w sensie Lema, niechybnie doprowadzi do ingerencji w tę spuściznę. W konsekwencji stosowania inżynierii genetycznej, jak również substancji psychotropowych pokroju prozaku czy ritalinu oraz selekcji zarodków, człowiek utraci to, co konstytuuje go w sposób genetyczny i kulturowy. Przekształcenie natury ludzkiej polegajace na osłabieniu pierwiastka emocjonalnego, jak twierdzi Fukuyama, upodobni ludzi do maszyn czy innych przedmiotów, będzie więc stanowiło raczej „dewolucję”, a nie rozwój ${ }^{10}$.

Przywiązanie do obecnego kształtu gatunku Homo sapiens i przerażenie w obliczu planu jego radykalnego przekształcenia to zreszta odczucia, które nieobce są również zwolennikowi autoewolucji - zauważa autor Summy... i dodaje: „Uważa [on] jednak tę przyszła przemianę za nieuchronną i właśnie dlatego szuka wszystkich racji, jakie by za nia przemawiały, tak aby działanie konieczne pokryło się z rezultatem wyboru" ${ }^{11}$. Być może ten właśnie cytat najlepiej oddaje rozterki samego Lema, który z jednej strony - jako absolwent medycyny - zdaje sobie doskonale sprawę z możliwego dobroczynnego

10 F. Fukuyama, Koniec człowieka. Konsekwencje rewolucji biotechnologicznej, Kraków 2004, s. 190-192, 222-224, 227n.

11 S. Lem, Summa technologiae, dz. cyt., s. 319. 
wpływu technologii autoewolucyjnych, a z drugiej - jako człowiek kultury - sam wzdraga się przed literalnie nieludzkimi konsekwencjami radykalnego odejścia od ograniczeń cielesności. Z tej perspektywy rozdział Paszkwil na ewolucję prezentuje się jako szczególna forma autoperswazji. Wewnętrzne rozdarcie autora Summy... odzwierciedliło się w jego późniejszym pisarstwie. Z jednej strony powstały bowiem teksty o podobnej wymowie, co autoperswazja z Summy..., takie jak obszerne fragmenty Golema XIV (1981) czy Wilhelm Klopper, „Die Kultur als Fehler” z tomu Doskonała pró $\dot{z}$ nia (1971), z drugiej strony fragmenty mocno krytyczne wobec idei autoewolucji, takie jak dodany w III wydaniu Filozofii przypadku (1988) rozdział XI poświęcony kryzysowi kultury, wypowiedź w 291. numerze „Znaku” z 1978 roku czy przede wszystkim komiczna, a zarazem przejmująco gorzka Podró ̇̇ dwudziesta pierwsza z Dzienników gwiazdowych (1971).

Łatwo dostrzec, że w świetle tych ostatnich Lem jawi się jako zwolennik tradycyjnych, osadzonych w aktualnej kondycji ludzkiej, systemów wartości, a zarazem ponury prorok degeneracji cywilizacji przytłoczonej otchłanią możliwości oferowanych przez technologię samowytwórcza, która, mówiąc jego słowami, okrucieństwa starych ograniczeń zastapi kiedyś okrucieństwami ich zupełnego braku ${ }^{12}$.

Jednak i w tej pierwszej grupie tekstów zawsze pobrzmiewa nuta goryczy. Superkomputer GOLEM XIV wieszczy, że człowiek stanie w końcu w obliczu niewygodnego dylematu wynikającego ze zbytniej komplikacji nauki i technologii: albo przekaże stery rozwoju cywilizacyjnego swoim wytworom - sztucznym inteligencjom w rodzaju samego GOLEMA - albo dokona radykalnego autoewolucyjnego skoku, porzucajac biologiczne uwarunkowania własnej egzystencji. Innej opcji nie ma, ponieważ - jak argumentuje autor Summy... ustami swego nieosobowego bohatera - ewolucja, wytwarzajac Homo sapiens, dotarła już do granic własnych konstrukcyjnych możliwości ${ }^{13}$. GOLEM ubiera ów dylemat w coś w rodzaju przypowieści bądź

12 S. Lem, Dzienniki gwiazdowe, Kraków 2003, s. 120.

13 Pogląd ten zarysował Lem już w 1957 roku w Dialogach (S. Lem, Dialogi, Warszawa 2010, s. 81). 
bajki, której morał brzmi: „w lewo pójdziesz - głowę stracisz; w prawo pójdziesz - zginiesz; a odwrotu nie ma"14.

Próżne i bezcelowe egzystowanie na łasce inteligentnych produktów cywilizacji technicznej hodujących swych twórców niczym rośliny doniczkowe, nie licuje z godnością człowieka. Wszystko wskazuje więc na to, że przetworzenie siebie wykraczające poza biologię oparta na białku i kodzie genetycznym okaże się jednak koniecznością. Jak mówi GOLEM:

Sądzę, że wejdziecie w wiek metamorfozy, że zdecydujecie się odrzucić cała swoją historię, całe dziedzictwo, cały ostatek naturalnego człowieczeństwa, którego obraz, wyolbrzymiony w piękną tragiczność, skupiają lustra waszych wiar - że wykroczycie, bo nie ma innego sposobu - i w tym, co teraz jest dla was skokiem w czeluść tylko, dopatrzycie się wyzwania, jeśli nie urody, i jednak po swojemu postapicie - skoro, odrzucając człowieka, ocali się człowiek ${ }^{15}$.

Lecz i tu jest to konieczność niełatwa do przyjęcia, co zresztą nie umyka uwadze narratora opowieści. Stopniowość przemian spowoduje jednak, że tragizm i groza sytuacji uśmiercenia Homo sapiens rozpuszczą się w tysiącach drobnych kroków i decyzji.

Będzie to daleko zwyklej zachodziło... i w niejakiej mierze już zachodzi, już wam martwieją regiony tradycji, ona się wam już łuszczy, obumiera, i to właśnie przyprawia was o taki zamęt; więc jeśli tylko będziecie powściagliwi (to nie jest wasza cnota) - bajka sprawdzi się tak, że nie popadniecie w zbyt głęboką żałobę po sobie ${ }^{16}$.

Bodaj najbardziej negatywne stanowisko wobec autoewolucji wyraził Lem w publicznej dyskusji na temat relacji nauka-wiara, która miała miejsce w bazylice oo. dominikanów w Krakowie 17 listopada 1976 roku, a której tekst został następnie opublikowany

14 S. Lem, Golem XIV, Kraków 1999, s. 61.

15 S. Lem, Golem XIV, dz. cyt., s. 64.

16 S. Lem, Golem XIV, dz. cyt., s. 64. 
w 291. numerze miesięcznika „Znak”17. Być może wiązało się to z miejscem, tematyką i osobami współdyskutantów, z których jeden (Stanisław Grygiel) reprezentował stanowisko wybitnie konserwatywnej i antytechnicystycznej ${ }^{18}$ myśli metafizycznej, a dwaj pozostali (Jan Andrzej Kłoczowski OP i Michał Heller) byli duchownymi katolickimi. Temat autoewolucji - a ściślej mówiąc „autorewolucji”, bo chodziło o jej najbardziej radykalną wersję - pojawił się w kontekście wspomnienia o zagrożeniach dla wiary, jakie tkwią w rozwoju nauki. Lem przedstawił krótko wizję radykalnego przeprojektowania człowieka naturalnego w celu jego duchowego i cielesnego ulepszenia, po czym zwrócił uwagę na podstawowy problem tego przedsięwzięcia:

Rzecz w tym, że każdy system społeczny, filozoficzny, każda religia, każdy historyczny czas uznawał i zakładał zawsze te cechy i wartości, które tkwią w człowieku naturalnym. Człowiek naturalny był więc i jest „stała”, niezmiennikiem całej swojej historii. Łatwo mówić ogólnikowo o „lepszym człowieku”, ale w tradycji wszystkich ziemskich kultur, w systemach wiary czy filozofii, w kodeksach etycznych nie można znaleźć żadnych dyrektyw, które by pozwoliły określić, jaki miałby być ten człowiek „udoskonalony”. Wykraczając poza daną nam naturę rzeczy, tracimy wszelkie wsparcie normodawcze, prawodawcze, aksjologiczne, teologiczne, pozostajemy bez śladu kompasu - cała ta melioracyjna koncepcja zawisa w próżni. A jednak kiedyś można będzie realizować zmiany psychiczne i cielesne w bardzo wielkim zasięgu, i może nie zabraknąc fanatyków takiego działania. To jest bodaj największe z przyszłych zagrożeń. [...] Nauka nie może frontalnie uderzyć w opokę wiary [...], ale zastosowanie płodów nauki mogłoby, kto wie, unicestwić kiedyś wszelki podmiot wiary, to znaczy tak przekształcić ducha i ciało przyszłych ludzi, że już bodaj nie zasługiwaliby na miano ludzi w naszym rozumieniu ${ }^{19}$.

17 J.A. Kłoczowski OP, S. Grygiel, S. Lem, M. Heller, Dyskusja o nauce i wierze, „Znak” 291 (1978), s. 1139-1152.

18 Pojęcie filozofii antytechnicyzmu stosujemy za: J. Bańka, Filozofia techniki. Człowiek wobec odkrycia naukowego i technicznego, Katowice 1980, s. 76n.

19 J.A. Kłoczowski OP, S. Grygiel, S. Lem, M. Heller, Dyskusja o nauce..., dz. cyt., s. $1139-1152$. 
Podsumujmy zatem stanowisko Lema wobec autoewolucji. Z jednej strony dostrzega on jej nieuchronność - jest ona prostym przedłużeniem logiki rozwoju nauki i cywilizacji technicznej. Zdaniem autora Summy..., o ile cywilizacja ta nie załamie się w bliskiej przyszłości, technologiczne samoprzekształcanie człowieka będzie postępować, aż w końcu stanie się on wytworem w takim samym stopniu, w jakim są nimi inne elementy jego otoczenia.

$\mathrm{Z}$ drugiej strony Lem wyraża obawę, że porzucenie człowieka naturalnego na rzecz człowieka-wytworu będzie się wiązać z odrzuceniem dziedzictwa kulturowego wytworzonego przez tego pierwszego. Zachodzi bowiem ścisły związek między formą naszego ciała i jego ograniczeniami a naszymi fundamentalnymi wartościami, potrzebami egzystencjalnymi i całą sferą norm kulturowych.

Autor Summy... sam jednak diagnozuje własne obawy o los kultury jako nieracjonalne, albowiem nie da się jego zdaniem uzasadnić przywiązania do czegoś, co stanowi owoc ułomności. Jednak i ta diagnoza - na kolejnym piętrze autodiagnozy - ukazana zostaje jako próba przekonania samego siebie, że to, co nieuchronne - porzucenie Homo sapiens wraz z całym jego bagażem rozterek i wartości - nie będzie katastrofa, lecz procesem majacym również strony pozytywne.

$\mathrm{Na}$ dodatek, wniosek dotyczacy odrzucenia kultury człowieka naturalnego pociaga za soba poważny zarzut wobec samego projektu autoewolucji. Lem wskazuje bowiem, że pozbywając się ograniczeń narzuconych przez ewolucję biologiczna, pozbywamy się tym samym ugruntowania sądów normatywnych i wartościujących. Na jakiej więc zasadzie, wedle jakiego kryterium człowiek-produkt miałby być lepszy od człowieka naturalnego?

\section{Lem i filozofia kultury}

Pytanie o kryterium wartościowania produktów autoewolucji wiąże się ściśle z Lemowską koncepcją kultury i racjonalności. Autor Summy... deklarował się jako racjonalista, przy czym, jak dodawał, racjonalista nie w pełni konsekwentny. Co więcej, uważał, że w pełni konsekwentny racjonalizm jest niemożliwy i pewne normy naszych 
działań i wartościowań pozostaną nieuzasadnione. „Racjonalizm stwierdzał - jest dowodliwy w obrębie łańcuchów uruchomionego działania, ale zawsze istnieje taki człon łańcucha, którego się logicznie nie uzasadni”"20.

Ów pozaracjonalny element systemu przekonań i wartości niekonsekwentnego racjonalisty to oczywiście kultura. Lem miał pełna świadomość jej wielorakich uwarunkowań biologiczno-historycznych, jej nieustannej zmienności i braku trwałego (metafizycznego) ugruntowania każdej z jej norm. Należał do szerokiego grona myślicieli, którzy diagnozowali głęboki kryzys kultury we współczesności, jednak odznaczał się wśród nich oryginalną teorią tłumacząca jego przyczyny.

Zarówno w publicystyce - obszernie polemizując z tezami Leszka Kołakowskiego wyrażonymi w głośnym odczycie Odwet sacrum w kulturze świeckiej (1972) - jak i w dziełach beletrystycznych Lem zarysował koncepcję kultury jako specyficznego mechanizmu regulacji zachowań, który zastapić musiał wycofywany w toku ewolucji mechanizm oparty na instynkcie. Powstanie kultury wiązało się z nieregularnością strategii Natury (zmiany klimatyczne, katastrofy geologiczne itp.), z którą organizmy żywe grają o przeżycie. Gdyby strategia ta była ściśle regularna, kultura nie mogłaby powstać, bowiem organizmy wykształciłyby w odpowiedzi ściśle regularne strategie przeżywania, a do tego wystarcza sam kod genetyczny. Tymczasem jednak gra premiowała organizmy, których zachowania były bardziej plastyczne, a mózg potęguje ową plastyczność. „Kultura - pisał Lem umożliwia to, co biologicznie niemożliwe: tworzenie strategii zarazem rewolucyjnych i odwracalnych, to jest dających się rewidować i przekształcać w tempie nieosiagalnym dla plazmy dziedzicznej”"1.

Kultura, podobnie jak każdy system dynamiczny, musi działać przeciwlosowo - życie to utrzymywanie i wytwarzanie ładu. Przeciwlosowość kultury objawia się jednak na wyższym poziomie niż przeciwlosowość życia, albowiem kultura to nie tylko gra z Natura,

20 J.A. Kłoczowski OP, S. Grygiel, S. Lem, M. Heller, Dyskusja o nauce..., dz. cyt., s. 1144 .

21 S. Lem, Filozofia przypadku, t. II, Warszawa 1997, s. 21. (Rozdział XI Filozofii przypadku, z którego pochodzi ten fragment, miał zupełnie inną treść w pierwszych wydaniach). 
ale również jej interpretacja. Kultura wytwarza obraz gry i ten obraz też jest przeciwlosowy w tym sensie, że przypisuje grze cechy, których ta w rzeczywistości nie posiada. Kultura jest więc medium, które częściowo izoluje swoich twórców od losowego charakteru środowiska, kamuflując go obrazem struktury pseudoregularnej ${ }^{22}$. Krótko mówiąc, zdaniem Lema, jedna z istotnych funkcji kultury jest zafałszowywanie rzeczywistości, aby była ona bardziej „strawna” dla ludzi. Kultura kłamie przede wszystkim o sobie samej, ukrywając własną naturę i pochodzenie - musi być niewidoczna i „przezroczysta” dla swych przedstawicieli, mają oni rozpoznawać jej struktury jako struktury samej rzeczywistości.

Obraz kultury jako fałszu nie jest oczywiście niczym nowym jego korzeni można doszukiwać się już u Platona, a może i jeszcze głębiej w historii filozofii. Oryginalność diagnozy Lema polega jednak na tym, że jego zdaniem fałsz kultury jest pożyteczny, dobrze spełnia bowiem cele, ze względu na które ona zaistniała. W Golemie XIV włożył w usta superkomputera następującą wypowiedź:

Kultura jest instrumentem niezwykłym przez to, że stanowi odkrycie, które, żeby działać, musi być zakryte przed swymi twórcami. To wynalazek bezwiednie sporządzony i póty pełnosprawny, póki nie rozpoznany do końca przez wynalazców. Paradoksalność jej w tym, że od rozpoznania ulega zapaści; będąc jej autorami, wypieraliście się tedy autorstwa; nie było w eolicie żadnych seminariów na temat, czy paleolit robić; przypisywaliście jej wejście w was demonom, żywiołom, duchom, siłom ziemi i nieba, byle tylko nie - samym sobie. Tak więc racjonalne - wypełnianie pustki celami, kodeksami, wartościami - czyniliście irracjonalnie, każdy swój rzeczowy krok uzasadniając ponadrzeczowo, łowiąc, tkając, budując w solennym samowmówieniu, że to wszystko nie z was, lecz z niedocieczonych źródeł. Osobliwy instrument - i właśnie racjonalny w swej irracjonalności, ponieważ nadawał instytucjom ludzkim ponadludzka godność, aby się stały nietykalne i zniewalające bezwzględnie do posłuchu $[\ldots]^{23}$.

22 S. Lem, Filozofia przypadku, dz. cyt., s. 22.

23 S. Lem, Golem XIV, dz. cyt., s. 30n. 
Z takiej teorii kultury właściwie od razu wynika pewna diagnoza przyczyn jej kryzysu - to właśnie zbyt dobrze rozwinięta samoświadomość człowieka, która zdemaskowała ukryte mechanizmy kultury, jest winna tej zapaści. To prowadzone w humanistyce wieloaspektowe poszukiwanie prawdy o człowieku doprowadziło do zachwiania najważniejszego mechanizmu regulacyjnego społeczeństwa. Kryzysowi winien jest zatem nie upadek kategorii sacrum, jak sądził Kołakowski ${ }^{24}$, lecz rozwój antropologii porównawczej, która odkryła różnorodność, a zatem i względność kultur i w ten sposób podkopała autorytet wszelkiej normy i systemu wartości.

Co ciekawe, w innych tekstach Lema na plan pierwszy wysuwa się odmienne zagrożenie dla kultury: cywilizacja naukowo-techniczna. Po pierwsze, w przeciwieństwie do kultury, nauka stara się odkrywać realne cechy rzeczywistości, wytwarza zatem jej obraz w miarę adekwatny. Z tego względu nie wpisuje się oczywiście w pseudoregularna strukturę kultury, stanowi więc wobec niej element obcy, a jej rozwój - niedający się w żaden sposób przewidzieć - jest czynnikiem z punktu widzenia kultury losowym.

Mechanizm degeneracji wyjaśnia pojawiający się już w Dialogach cybernetyczny model umysłu (systemu inteligentnego), którego struktura powtarza się jako model kultury w XI rozdziale Filozofii przypadku. Każda kultura jest konkretną realizacją ogólnego schematu dynamicznego krążenia informacji. Informacja przepływa przez układ, którego najistotniejszym elementem funkcjonalnym jest filtr preferencji oddzielający treści nieakceptowane od tych, które układ będzie reprodukował. Filtr stanowi wewnętrzny element strukturykonstytuuje go informacja przechowywana w pamięci systemu ${ }^{25}$. Model z wewnętrznym filtrem stanowi ciekawą alternatywę dla rozwijanej w połowie XX wieku przez Romana Ingardena koncepcji systemu względnie izolowanego, w którym rolę filtra odgrywa półprzepuszczalna zewnętrzna osłona ${ }^{26}$ - oba rozwiązania proponują strukturalne

24 L. Kołakowski, Odwet sacrum w kulturze świeckiej, w: Czy diabeł może być zbawiony i 27 innych kazań, Kraków 2006, s. 234-247.

25 S. Lem, Filozofia przypadku, dz. cyt., s. 64-66.

26 R. Ingarden, O odpowiedzialności $i$ jej podstawach ontycznych, w: Ksiażeczka o człowieku, Kraków 1972, s. 133-161. 
wyjaśnienie częściowej (ale tylko częściowej) niezależności systemów od warunków zewnętrznych. Lemowski kulturowy filtr preferencji sam podlegać może modyfikacji - pewne informacje mogą być nie tylko przepuszczone do reprodukowania, ale również moga same stać się elementami zbioru kryteriów preferencji. Z kolei zbiór ten nie może być zbyt rozbudowany, ponieważ efektywna pamięć każdego systemu jest zawsze ograniczona; oznacza to, że dodanie nowego kryterium preferencji może przesłonić bądź wyeliminować stare kryterium.

Jeśli proces przemian filtra będzie zbyt szybki i chaotyczny, jego dynamiczna równowaga zostanie zakłócona, a sprawność funkcjonowania jako selektora informacji stale napływających z otoczenia spadnie. Z tego względu nowe kryteria selekcji nie moga być dobierane w sposób całkowicie przypadkowy i powinny harmonizować z kryteriami już istniejacymi. W przeciwnym razie dochodzi do kryzysu, to znaczy do sytuacji, w której filtr przestaje spełniać swoja funkcję czynnika przeciwlosowego i system zaczyna reprodukować informacje w sposób przypadkowy. Lem twierdzi, że taka sytuacja de facto już ma miejsce w systemie, jakim jest nasza kultura, który jak twierdzi za Kołakowskim - wykazuje wiele symptomów rozkładu. Dzieje się tak, ponieważ postęp naukowo-techniczny dokonuje się już zbyt szybko i - jak wcześniej zauważyliśmy - jest z punktu widzenia kultury całkowicie nieprzewidywalny.

Czy jednak cywilizacja naukowo-techniczna i wpisana w nią idea postępu jest całkowicie neutralna i sama nie zakłada pewnych wartości? Lem dostrzega, że tak oczywiście nie jest. Po pierwsze, nauka narodziła się w pewnej konkretnej kulturze, po drugie, przez długie stulecia utrzymywał się w niej kulturowo warunkowany lęk przed przypadkowością. Po trzecie wreszcie, pewien zestaw wartości jest nieodzowny dla samego istnienia nauki, a najważniejszą z nich jest oczywiście prawda. Dlatego Lem wspomina o możliwości podporządkowania kultury rozwojowi nauki - o jej ukierunkowaniu ideą postępu technologicznego. Możliwość ta - do pewnego stopnia realizowana w naszych czasach - jest jednak na dłuższą metę zabójcza dla kultury.

Kultura, przytroczona do instrumentalizmów, jest kulturą rozrywana, tracącą ciagłość diachroniczną oraz synchroniczną spójność. Na te naciski 
odpowiada gwałtowniejąca mutabilnościa, coraz bardziej poronną: cokolwiek spłodzone, będzie natychmiast zmyte falą następnych innowacji tak samo abortywnych ${ }^{27}$.

Można powiedzieć, że w świetle zarysowanej przed chwilą Lemowskiej koncepcji kultury wartości epistemiczne związane z realizacja idei postępu naukowo-technicznego nie nadają się na szkielet kultury, ponieważ to właśnie ich realizacja stanowi podstawowy czynnik decydujacy o jej rozkładzie. Prawda - definiowana rzecz jasna w kontekście metody naukowej, a nie np. filozofii platońskiej czy teologii chrześcijańskiej - okazuje się zatem wartościa pozakulturową - wręcz antykulturowa - jedyna, która wspólna jest ludziom i bezosobowemu wcieleniu racjonalności, jakim jest GOLEM XIV, który nie ma i nie potrzebuje kultury, przejawia natomiast ciekawośćc ${ }^{28}$.

Złożone, lecz jednoznacznie pesymistyczne stanowisko Lema, stanowiące owoc jego refleksji nad wpływem postępu technologicznego na kulturę, ostro kontrastuje z wizjami snutymi przez przedstawicieli transhumanizmu nastawionymi, rzecz jasna, znacznie bardziej optymistycznie do idei autoewolucji człowieka. Wymownym przykładem może być koncepcja zaprezentowana przez amerykańskiego publicystę Joela Garreau, który w swojej popularyzatorskiej książce zatytułowanej Radykalna ewolucja. Czy człowiek udoskonalony przez naukę i technikę będzie jeszcze człowiekiem? (2005) analizuje szereg scenariuszy związanych z urzeczywistnieniem transhumanistycznych postulatów. Sam autor opowiada się za „triumfalną” wersja przyszłości. Opcja ta nie zakłada hiperoptymistycznego scenariusza, wedle którego postęp technologiczny wyzwoli ludzkość ze wszystkich dręczących ją dolegliwości. Niemniej jednak jest to nadal stanowisko zakładające generalnie pozytywne rezultaty lawinowego powiększania się ludzkich możliwości przekształcania rzeczywistości dzięki postępującemu wykładniczo rozwojowi czterech nauk: genetyki, robotyki, informatyki i nanotechnologii. Wśród korzyści wynikających z tego zjawiska Garreau wymienia w szczególności

27 S. Lem, Filozofia przypadku, dz. cyt., s. 41.

28 S. Lem, Golem XIV, dz. cyt., s. 25. 
zwiększenie możliwych form interakcji międzyludzkich i sposobów ekspresji. Jako przykład podaje zdolność wykorzystania powierzchni ciała do „projekcji” modyfikowalnych wzorów (taka forma komunikacji występuje w naturze - posługują się nią np. niektóre gatunki mątw) ${ }^{29}$; również Lem wykorzystuje ten pomysł w kontekście autoewolucji w Podróży dwudziestej pierwszej ${ }^{30}$. Choć autor Radykalnej ewolucji nie stosuje w tym kontekście terminu autentyczność, można chyba zaryzykować stwierdzenie, że ów wzrost możliwości ekspresji rozumiany jest przez niego jako poszerzenie pola autentyczności.

Garreau w swojej książce wskazuje również na zagrożenia. Częściowo pokrywają się one z tymi, które wskazał Fukuyama w Końcu człowieka, a także Lem w Filozofii przypadku - chodzi przede wszystkim o gwałtowność nadchodzących zmian. Jednak w przeciwieństwie do wymienionych krytyków wizji transhumanistycznej autor Radykalnej ewolucji stara się nakreślić pewne propozycje neutralizacji tych zagrożeń. Snuje wizję humanizacji, „oswajania” nowej rzeczywistości poprzez rytualizację, a więc nadanie kulturowego znaczenia ważniejszym zabiegom technologicznego usprawniania jednostki. Przykładowo, wszczepieniu kilkulatkowi pierwszego implantu wspomagającego zdolności percepcyjne towarzyszyłby rodzaj ceremonii angażującej rodzinę i znajomych, związanej z ustalonymi zwyczajami, na wzór obecnych zachowań społecznych zwiąanych z uroczystością pierwszej komunii świętej. Garreau spekuluje, że w ten sposób technologia przedłużająca i ulepszająca ludzkie życie może również pozytywnie wpływać na proces socjalizacji, a w konsekwencji na poprawę jakości życia jednostkowego także w wymiarze duchowym:

Czy takie rytuały przyniosa coś dobrego? Nie wiem. Czy chrzty, śluby i pogrzeby - uświęcenie narodzin, kopulacji i śmierci - przyniosły coś dobrego? Z mojego doświadczenia mogę powiedzieć, że tak. Przynajmniej sa to rytuały przejścia, odprawiane, kiedy ludzie przekraczaja

29 J. Garreau, Radykalna ewolucja. Czy człowiek udoskonalony przez nauke i technikę będzie jeszcze człowiekiem?, tłum. A. Michalski, Warszawa 2008, s. 208$211,230$.

30 S. Lem, Dzienniki gwiazdowe, dz. cyt., s. 114. 
granice - klas, płci, regionu, rasy i religii. Gromadzą nas razem, oficjalnie znacząc i pokazując decydujące momenty. Następuje wówczas integracja między ludźmi, jaka rzadko ma miejsce w innych okolicznościach. [...] Gdy tak zrobimy, zapraszając na taką ceremonię wszystkich ludzi spotkanych podczas spaceru przez życie na wszystkich poziomach zdolności, jeszcze mocniej będzie to splatać tkaninę złożoną ze wszystkich rodzajów ludzkiej natury, jakie się pojawia. Pozwoli to nam osiagnąć [...] rodzaj szczęścia - szczęścia stanowiącego część czegoś znacznie większego niż my sami. Pozwoli to nam kontynuować pochód w górę rampy połączeń między ludźmi. [...] być może będzie to po prostu ostateczna transcendencja ${ }^{31}$.

Propozycję Garreau możemy uznać za swoistą ekstrapolację praktyk opisywanych przez Mumforda: postulat rytualizacji technologii ma na celu doprowadzenie do jej ponownej konwergencji z kultura. W oczach Lema byłaby to jednak właśnie forma „przytroczenia” tej ostatniej do tej pierwszej, a więc coś, co w pewnym stopniu dzieje się już teraz (w tym kontekście można przywołać choćby praktykę święcenia samochodów, która przez część wiernych odbierana jest jako dziwactwo, a więc coś, co nie zdążyło się jeszcze zakorzenić w kulturze). Podstawowym problemem pozostaje tempo przemian w odniesieniu do przykładu Garreau można prognozować, że wraz z postępem w nanotechnologii i genetyce procedura wszczepiania implantu straci w końcu sens, ponieważ rozwiną się nowe, znacznie bardziej subtelne sposoby augmentacji, które będą polegać np. na zastosowaniu nanorobotów już na etapie życia płodowego ${ }^{32}$. W takiej rzeczywistości ceremonie proponowane przez autora Radykalnej ewolucji stracą rację bytu.

31 J. Garreau, Radykalna ewolucja..., dz. cyt., s. 270n.

32 W zasadzie trudno nawet powiedzieć, czy epoka usprawniania poprzez operacyjne wszczepianie tego rodzaju implantów w ogóle nadejdzie, nie da się bowiem formułować stuprocentowo pewnych przewidywań co do szybkości rozwoju konkretnych technologii. 


\section{Dwie koncepcje autentyczności}

Dlaczego w naszych rozważaniach dotyczących - mówiąc ogólnie antropologii Lema chcemy posłużyć się pojęciem autentyczności? Ponieważ pojęcie to, naszym zdaniem, może stanowić klucz do odpowiedzi na pytanie „kim jest człowiek?” w sytuacji, w której nie da się już odwołać się do metafizycznego pojęcia istoty.

Opcja metafizyki istoty jest dla autora Dialogów niedostępna, gdyż jako darwinista przyjmuje on, że człowiek to niedoskonały twór ewolucji biologicznej, którą rządzi przypadek i mechanizmy eliminacji form gorzej przystosowanych do środowiska. Nie było żadnego planu, żadnego wzorca - Natura jest ślepa i nie podporządkowuje się żadnej teleologicznej zasadzie. Pojęciu gatunku człowieka nie odpowiada więc ani platońska idea, ani arystotelesowska forma, a jedynie pewna mnogość cech morfologicznych i behawioralnych skorelowana $\mathrm{z}$ określonym wzorcem informacji genetycznej charakteryzująca zbiorowość osobników, które mogą się krzyżować i mieć płodne potomstwo. Rzecz jasna, specyfika Homo sapiens jest znaczenie, jakie w obrębie gatunkowych cech behawioralnych zajmują dyspozycje do nabywania we wczesnym okresie życia formy kulturowej, a więc przede wszystkim języka i siatki pojęciowej w znaczącym stopniu wpływającej na percepcję otoczenia; formę tę niektórzy filozofowie skłonni są nazywać - za Arystotelesem - „drugą natura” ${ }^{33}$. Wszelako Lem jednoznacznie odcina możliwość wprowadzenia metafizycznej teleologii „tylnymi drzwiami” kultury - narzędzia odkrywającego jakoby obiektywne struktury wartości - ponieważ ją również rozumie wyłącznie w kategoriach funkcji adaptacyjnej (choć dostrzega jej specyfikę).

Postmetafizyczny ideał autentyczności można jednak rozumieć na dwa zasadnicze sposoby. Po pierwsze, wedle perspektywy Nietzscheańsko-Sartre'owskiej, w której chodzi o radykalne zerwanie z wszelkimi zewnętrznymi uwarunkowaniami pojmowanymi negatywnie, tj. jako ograniczenia dla autokreacji wolnej jednostki

${ }^{33}$ Zob. np. J. McDowell, Mind and World, Cambridge (MA) 1994, s. 84. 
ustanawiającej swoją własną istotę ${ }^{34}$. Owo ustanawianie - akt nieskrępowanego tworzenia - powtarzany jest w każdej nowej decyzji wypływającej z absolutnie suwerennej świadomości interpretowanej ontologicznie jako intruzja nicości w martwym (bo spętanym deterministycznymi prawami przyczynowości) bycie ${ }^{35}$. W praktyce realizacja wartości autentyczności polega więc dla zwolenników Nietzschego i Sartre'a na wdrażaniu w życie własnego „pomysłu na siebie” niezależnie od zastanych uwarunkowań społecznych i kulturowych, na wolnym i nieskrępowanym wyborze modelu życia, na swobodnym konstruowaniu systemu wartości, który nie musi cechować się ani spójnością wewnętrzna, ani ścisłą hierarchia, ani nawet trwałością ${ }^{36}$.

Po drugie, w perspektywie myśli późnego Heideggera ${ }^{37}$ i późnego Wittgensteina, „bycie sobą” może wiązać się nie tyle z nieskrępowana twórczością i swobodą wyboru stylu życia, ile z cierpliwym i wytężonym „wsłuchiwaniem się” w „mowę bycia” jako czegoś już zastanego. „Człowiek nie jest panem bytu - pisze Heidegger w Liście o humanizmie, eseju skierowanym przeciw filozofii Sartre’a - Człowiek jest pasterzem bycia" ${ }^{38}$. Heideggerowskie udzielanie się bycia nie ma oczywiście nic wspólnego z objawianiem metafizycznej istoty - można je interpretować jako dziejowy proces rozwoju tradycji kulturowej, który nie jest ani ściśle regulowany żadnymi teleologicznymi (a tym bardziej deterministycznymi) zasadami, ani nie jest też czysto przypadkowy. Samorozumienie oraz autentyczne projektowanie siebie

${ }^{34}$ Charakterystyczny wyraz stanowiska Nietzschego znajdziemy np. w mowie Zaratustry $O$ trzech przemianach, w której pada wezwanie do walki ze smokiem zwanym „musisz” (zob. F. Nietzsche, Tako rzecze Zaratustra. Ksiażka dla wszystkich $i$ dla nikogo, tłum. W. Berent, Poznań 2006, s. 22-24).

${ }_{35}$ J.-P. Sartre, Byt i nicość. Zarys ontologii fenomenologicznej, tłum. J. Kiełbasa, P. Mróz i in., Kraków 2007, s. 61n.

36 Jak wskazuje np. Markus Lipowicz, konsekwencją próby realizacji takiego ideału autentyczności jest destrukcja więzi społecznych (M. Lipowicz, Czy „śmierć boga” jest „śmiercia społeczeństwa”? Próba połaczenia wybranych aspektów filozofii Fryderyka Nietzschego z filozofia i socjologia Georga Simmla, „Diametros” 37 (2013), s. 98).

37 Jak wskazują interpretatorzy myśli Heideggera, przejście do późnej fazy jego filozofii łączy się z odejściem od Nietzschego (zob. np. M. Drwięga, Człowiek w filozofii Martina Heideggera, „Kwartalnik Filozoficzny” XL (2012), z. 3, s. 62n).

38 M. Heidegger, List o humanizmie, tłum. J. Tischner, Warszawa 1977, s. 104. 
nie może się zatem odciąć od własnej tradycji, jest więc współokreślane momentem dziejowym kultury, w którą ludzkie jestestwo (Dasein) wraz ze swoją wolnościa jest „rzucone” ${ }^{39}$. Przede wszystkim jednak „rzucone” jest ono w bycie-ku-śmierci, a więc sytuację, w której biologiczne ograniczenia stawiają ostateczny opór wszelkiej możliwej autokreacji. Śmierć jako „możliwość niemożliwości” wyznacza kres wszelkim indywidualnym projektom, nadaje również „eschatologiczną" powagę stojącemu przed człowiekiem zadaniu rozumienia własnego bycia. Właściwy sens bycia człowiekiem jest zatem nie do pomyślenia w abstrakcji od horyzontu śmiertelności, a ogólniej, od horyzontu cielesności i „ludzkiej formy życia” ${ }^{40}$. Ta ostatnia stanowi twarde podłoże naszych kulturowo kształtowanych przekonań, kategorii i wartości, ponieważ to z niej wypływają nasze najbardziej podstawowe działania i pierwotne reakcje.

Wedle drugiego ujęcia autentyczność nie wiąże się ani ze spontanicznym „przewartościowywaniem wszystkich wartości”, ani z podejmowaniem absolutnie suwerennych wyborów przy świadomości ich całkowitego nieuwarunkowania, ani z fastrygowaniem „patchworkowej” moralności na własną miarę. Wartości się dziedziczy - współkonstytuuja one tożsamość, która z tego powodu przynajmniej częściowo poprzedza jednak egzystencję. Nie zamyka to oczywiście drogi do jej modyfikacji, lecz modyfikacja ta w żadnym razie nie powinna zachodzić na drodze arbitralnych decyzji absolutnie suwerennego

39 Ciekawą analizę relacji wolności do dziejów w myśli późnego Heideggera na podstawie jego dwóch esejów - $O$ istocie racji i $O$ istocie prawdy - przedstawia Marcin Polak (zob. M. Polak, Urojone-nic. Postmodernistyczna metafizyka Stanislasa Bretona, Kraków 2014, s. 101-103).

40 Choć pojęcie Lebensform pojawia się w kilku miejscach w pismach Wittgensteina z późnego okresu twórczości (polski tłumacz Dociekań filozoficznych dość niefortunnie przełożył je jako „sposób życia”), to fraza menschliche Lebensform nigdy nie została przezeń użyta. Wielu komentatorów wskazuje jednak na fakt, że pojęcie „ludzkiej formy życia” mieści się w ramach jego filozofii (zob. np.: O. Hanfling, Wittgenstein and the Human Form of Life, London - New York 2002, s. 5; J. Gomułka, M. Szafrański, Wittgensteinowska „forma życia” $i$ biologiczne podstawy gramatyki, „Semina Scientiarum” 8 (2009), s. 58), czego dowodzi choćby uwaga o lwie, którego nie potrafilibyśmy zrozumieć, choćby nawet nauczył się mówić - nie mielibyśmy wspólnej z nim formy życia (zob. L. Wittgenstein, Dociekania filozoficzne, tłum. B. Wolniewicz, Warszawa 2000, s. 313). 
podmiotu (który jest zresztą zawsze iluzorycznym konstruktem, a nie podmiotem rzeczywistym). Trwałość struktur kulturowych - nawet tych najbardziej podstawowych - jest zawsze tylko relatywna, przypomina ruchome koryto rzeki, które w metaforze Wittgensteina jest niezmienne względem przepływającej wody, ale jednak w dłuższej perspektywie czasowej przemieszcza $\operatorname{sie}^{41}$. I podobnie jak ekosystem rzeki może ulec zachwianiu, a nawet zagładzie na skutek planowych działań regulacyjnych, gdyż żaden model teoretyczny nie jest w stanie przewidzieć wszystkich swych rzeczywistych konsekwencji, tak też kultura i uwikłana w nią tożsamość jednostkowa narażone są na trudne do przewidzenia niebezpieczeństwa, gdy usiłuje się je przeprojektowywać w duchu racjonalnych ideologii. Jest to w każdym razie prosta droga do utraty autentyczności.

Nietrudno dostrzec, że Lem opowiada się za drugim sposobem rozumienia autentyczności, przy czym jego ponure autoewolucyjne prognozy zakładają nadejście epoki Nietzscheańsko-Sartre’owskiej. GOLEM XIV wróży ludzkości niemal absolutną wolność, przy czym określa ją mianem najcięższego z czekających nas zadań. Prześcignięcie Natury oznacza wyzwolenie się z jej ograniczeń, w tym także z ograniczenia śmiertelności, a być może również $\mathrm{z}$ aktualnie obowiąujących praw fizyki. Sytuacja, w której człowiek osiagnie taka wolność, nie będzie miała nic wspólnego z radosną twórczą ekstaza, lecz raczej z groteskowym miotaniem się między skrajnościami. Absolutną wolność autokreacji mnich-robot z Podróży dwudziestej pierwszej nazywa otchłanną i w kategoriach wysublimowanej dialektycznej teologii czwartego tysiąclecia utożsamia z Szatanem ${ }^{42}$. To właśnie gwoli wyrażenia siebie i ekspresji swojej autentyczności rozumianej rzecz jasna po Nietzscheańsku - powstały na Dychtonii niezliczone formy transludzi, niekoniecznie antropomorficzne ( $\mathrm{np}$. zmiennokształtni rozlewici, zwani prześmiewczo „kałużanami”), stanowiące często parodię wizerunku człowieka poprzez groteskowa multiplikację narządów czy kończyn. Nawet prawne próby ujednolicenia, ustandaryzowania lub choćby ograniczenia dokonywanych

\footnotetext{
${ }^{41}$ L. Wittgenstein, O pewności, tłum. W. Sady, M. Sady, Warszawa 1993.

42 S. Lem, Dzienniki gwiazdowe, dz. cyt., s. 131-133.
} 
modyfikacji okazały się nieskuteczne w zmaganiach z estetycznymi trendami i zróżnicowanymi utylitarnymi potrzebami. Z taką wizją Lema dobrze koresponduja słowa Fukuyamy, przestrzegającego przed „wyścigiem zbrojeń” w tworzeniu konstruktów genetycznych, mających sprostać określonym, często przeciwstawnym celom ${ }^{43}$. $\mathrm{Z}$ tego punktu widzenia nie można zatem mówić o bezwzględnej homogenizacji jako o celu autoewolucji.

Wybór w sytuacji całkowitego nieuwarunkowania nie może doprowadzić do realizacji żadnej autentycznej wartości, ponieważ autentyczność zakłada tożsamość, a więc pewną określoność. Co prawda, technologia autoewolucyjna ziści, teraz jeszcze nieprawdziwe, hasło Sartre'a - egzystencja wyprzedzi wszelką esencję - ale oznaczać to będzie, że wszystko, nawet twórczość, utraci sens, ponieważ nie będzie już przez nic określana. Paradoksalne zapętlenie homo faciens i homo factus to czarna dziura nihilizmu. Lem w Golemie XIV roztacza, co prawda, wizję możliwości wyjścia z tej pułapki, lecz ona również nie ma nic wspólnego $\mathrm{z}$ autentycznościa. Proroctwo GOLEMA mówi o formie bezosobowej inteligencji, w którą będzie musiała przeistoczyć się ludzkość, aby kontynuować panowanie nad rozwojem własnej cywilizacji. Jest ona ludziom jednak na tyle obca, że nie posiadaja nawet języka, aby o niej mówić - w końcu sama postać GOLEMA, jaką prezentuje powieść, to również efekt nieuniknionej antropomorfizacji (będącej po części efektem celowej autoantropomorfizacji inteligentnej maszyny).

\section{Przyczynek: autoewolucja z perspektywy Marksa}

Na zagadnienie autentyczności w kontekście transhumanizmu można spojrzeć również z perspektywy Marksowskiej teorii alienacji. Alienacja - a więc bytowanie nieautentyczne - według Marksa pojawia się w wyniku rozdźwięku pomiędzy twórca a jego wytworem wynikającego z nieposiadania przez twórcę środków produkcji, co jest związane z funkcjonowaniem prawa ochrony własności prywatnej

43 F. Fukuyama, Koniec człowieka..., dz. cyt., s. 134 n. 
w warunkach systemu kapitalistycznego. Prawo to powoduje, że faktyczny twórca - robotnik - popada w zależność od posiadacza środków produkcji. Zatem dopóki istnieje własność prywatna, dopóty pozostaje on wyalienowany od efektów swej pracy i jej sensu. Tym samym wyalienowany zostaje ze swej istoty - człowieczeństwa - albowiem:

właśnie przetwarzanie świata przedmiotowego stanowi dopiero rzeczywiste przyświadczenie człowieka jako istoty gatunkowej. Produkcja ta jest jego czynnym życiem gatunkowym. Dzięki niej przyroda staje się jego dziełem i jego rzeczywistością. Przedmiot pracy jest więc uprzedmiotowieniem życia gatunkowego człowieka: człowiek podwaja się nie tylko intelektualnie, jak w świadomości, lecz czynnie, rzeczywiście, i ogląda siebie w stworzonym przez siebie świecie. A więc praca wyobcowana, wydzierając człowiekowi przedmiot jego produkcji, wydziera mu tym samym jego życie gatunkowe, jego rzeczywista gatunkową przedmiotowość, i zmienia jego wyższość nad zwierzęciem w upośledzenie, polegające na tym, że zostaje on pozbawiony swego ciała nieorganicznego, przyrody ${ }^{44}$.

W konsekwencji tylko zniesienie prawa własności i doprowadzenie do ontycznej jedności pracownika i pracodawcy może zapobiec alienacji, a więc przywrócić człowiekowi jedność z samym soba i autentyczne życie.

Warto zauważyć, że ludzie poddawani modyfikacjom nie będa musieli być tymi, którzy owe modyfikacje będą projektować i wykonywać. Stwarza to możliwość pojawienia się zjawiska alienacji, a w konsekwencji utraty po Marksowsku rozumianej autentyczności. O ile jest możliwe, że na początkowym etapie testów pierwszymi podmiotami augmentacji będą sami naukowcy, a więc projektanci „nowego człowieka”, o tyle później, gdy technologia ulepszeń się rozpowszechni, modyfikacjom poddawani będą,zwykli” ludzie. Ci ostatni pozostaną zależni od specjalistów i operatorów technologii, a także, a może przede wszystkim - w rzeczywistości ekonomicznej opartej na własności prywatnej - od właścicieli i decydentów korporacji

${ }_{44}$ K. Marks, [Praca wyobcowana], www.nowakrytyka.pl/spip.php?article576 (29.04.2015). 
działających w nowej dziedzinie gospodarki, jaką stanie się przemysł autoewolucyjny. W takich warunkach hasło „tworzenia siebie samego" będzie tylko marketingową zasłoną kryjąca alienujące zapośredniczenie relacji człowieka do siebie samego - stanie się on bowiem nie tylko produktem, ale również towarem, który sam nabywa od kogoś innego ${ }^{45}$.

Kwestia alienacji wiąże się też nierozerwalnie ze zjawiskiem, w którym praca człowieka zaczyna niejako „żyć własnym życiem”. W przypadku marksistowskiej wizji ekonomii wynika to z zawłaszczenia tak powstałego kapitału przez pracodawcę-kapitalistę na jego potrzeby (w procesie akumulacji). Pracownik nie ma dalszego wpływu na to, co dzieje się z jego produktem. Odnosząc to per analogiam do filozofii technologii i potencjalnych scenariuszy przyszłości, jedna wizja zdaje się stanowić pożądaną formę wyrwania się z wyobcowania. Jeśli pojawi się sztuczna inteligencja w rozumieniu tzw. mocnego programu SI, efekt pracy ludzkiej literalnie zacznie „żyć własnym życiem”. W takim przypadku autoewolucja - ontyczne połaczenie tym razem twórcy i jego tworu - mogłaby dla odmiany stanowić środek prewencyjny, majacy na celu zapobieżenie takiej formie alienacji. Dotyczyłoby to jednak tylko samodoskonalącego się SI.

\section{Zakończenie}

W artykule staraliśmy się zaprezentować skomplikowane stanowisko Stanisława Lema wobec transhumanistycznego projektu autoewolucji człowieka na tle dwóch przeciwstawnych koncepcji autentyczności. W części pierwszej - mającej charakter wstępny odwołaliśmy się do rozważań Lewisa Mumforda, aby ukazać, że zjawisko samokształtowania jest właściwie tak stare jak gatunek Homo sapiens i poprzedza pojawienie się narzędzi technicznych. Oznacza to,

45 Warto zauważyć, że wizję takiej przyszłości - i oczywiście jej krytykę - kreśli również Heidegger w swojej późnej filozofii (zob. np. M. Drwięga, Człowiek w filozofii..., dz. cyt., s. 66). 
że idea autoewolucji jest - wbrew temu, co można by sądzić - mocno zakorzeniona w kulturze.

W części drugiej zaprezentowaliśmy ambiwalentne poglądy Lema na autoewolucję na podstawie różnych źródeł (beletrystyki, eseistyki, wypowiedzi w debacie publicznej). Postawiliśmy tezę, że odnoszący się do projektu autoewolucji fragment Summy technologiae, a także inne pozycje, w których autor stara się bronić tej idei, maja charakter autoperswazyjny. Pisarz jest bowiem przekonany, że nadejście epoki technologicznego samoprzekształcania człowieka jest nieuchronne; jest też świadomy możliwych negatywnych konsekwencji tego procederu, próbuje zatem przekonywać siebie samego, że ma on również strony pozytywne i nie jest w gruncie rzeczy taki straszny.

Część trzecia dotyczy filozofii kultury Lema zrekonstruowanej przede wszystkim na podstawie XI rozdziału Filozofii przypadku. Diagnoza współczesności zaprezentowana przez autora ma charakter pesymistyczny. Uważa on bowiem kulturę za dobrze działający mechanizm przystosowawczy gatunku Homo sapiens, którego funkcja polega w znacznej mierze na zafałszowywaniu obrazu rzeczywistości (w tym zafałszowaniu roli samej kultury) i którego sprawne działanie jest możliwe, dopóki prawda nie wyjdzie na jaw, a to się już zasadniczo dokonało. Co więcej, wrogiem kultury jest technologia, ponieważ dokonuje ona realnych, a nie tylko symbolicznych zmian w rzeczywistości, co powoduje, że kulturowe regulacje stają się nieadekwatne. $\mathrm{Z}$ wizji Lema wynika więc jednoznacznie, że rozwój nauki zagraża kulturze. Zagrożenie to jest podwójne, płynie bowiem, po pierwsze, ze strony empirycznej humanistyki (antropologia kulturowa, językoznawstwo, socjologia), która obnaża jej arbitralność, po drugie, ze strony sciences, które badając świat, tworza jego obraz względnie niezależnie od tradycyjnego obrazu kulturowego, a do tego wyposażają ludzkość w narzędzia do coraz dalej idącej modyfikacji otoczenia. Wszystko to powoduje więc, że żyje ona w czasach narastającego kryzysu, wręcz zaniku kultury, a to oznacza jednocześnie kryzys człowieczeństwa, bowiem czysta racjonalność - choć zasadniczo możliwa do wydestylowania z Homo sapiens w toku autoewolucji bądź wykreowania w procesie rozwoju sztucznej inteligencji - choć nie musi być monstrualna, to jednak jest nieludzka. 
W części czwartej zestawiamy ze sobą dwie koncepcje autentyczności, które różni podejście do problematyki wolności i tradycji. Wedle koncepcji Nietzschego i Sartre'a autentyczność wymaga absolutnej wolności i realizuje się w opozycji do wszelkich uwarunkowań. Heidegger i Wittgenstein mają zasadniczo odmienne zdanie - obaj rozumieją autentyczną egzystencję jako osadzoną w kulturze i w specyficznej „ludzkiej formie życia” zakładającej horyzont śmiertelności. Ten drugi sposób rozumienia charakterystyczny jest również dla Lema - na tym właśnie opiera się jego rezerwa wobec wizji transhumanistycznej.

Ostatnią część artykułu poświęciliśmy rozważaniom autentyczności przekształcającego się człowieka z perspektywy Marksowskiej teorii alienacji. Zwróciliśmy uwagę na fakt, że powszechna technologiczna augmentacja w warunkach gospodarki kapitalistycznej spowoduje nieuchronne utowarowienie nowej przeobrażonej tożsamości.

\section{Summary}

\section{The Human as a Self-Creation: Lem, Transhumanism, and Two Concepts of Authenticity}

Stanisław Lem, a philosopher and futurologist, in his many works devoted much attention to the condition of human and the relation between human and technology. He coined the term 'autoevolution' in the course of forecasting unlimited technological augmentation of human abilities. Nowadays, the term may be associated with the conceptions presented by transhumanism, a 20th-century-born philosophical movement which advocates radical transformation of Homo sapiens by means of the achievements of scientific and technological progress. Lem's attitude towards such a transformation of human is complicated yet ultimately critical due to the fact that it poses a threat to human culture as such. The phenomenon of autoevolution undermines existing values and raises a question of authenticity of a future posthuman. We examine dependence between technology and culture, present Lem's conception of autoevolution and his philosophy of culture, then we sketch a post-metaphysical dispute about authenticity, and finally show that Lem's thought belongs to one of the arguing sides.

Keywords: transhumanism, autoevolution, authenticity, Stanisław Lem 


\section{Bibliografia}

Bańka J., Filozofia techniki: Człowiek wobec odkrycia naukowego i technicznego, Katowice 1980.

Drwięga M., Człowiek w filozofii Martina Heideggera, „Kwartalnik Filozoficzny” XL (2012), z. 3, s. 43-67.

Fukuyama F., Koniec człowieka. Konsekwencje rewolucji biotechnologicznej, tłum. B. Pietrzyk, Kraków 2004.

Garreau J., Radykalna ewolucja. Czy człowiek udoskonalony przez nauke $i$ technike będzie jeszcze człowiekiem?, tłum. A. Kloch, A. Michalski,Warszawa 2008.

Gomułka J., Szafrański M., Wittgensteinowska „forma życia” i biologiczne podstawy gramatyki, ,Semina Scientiarum” 8 (2009), s. 56-78.

Hanfling O., Wittgenstein and the Human Form of Life, London-New York 2002.

Heidegger M., List o humanizmie, tłum. J. Tischner, Warszawa 1977.

Ingarden R., O odpowiedzialności i jej podstawach ontycznych, w: Ksiażeczka o człowieku, Kraków 1972, s. 133-161.

Kłoczowski OP J.A., Grygiel S., Lem S., Heller M., Dyskusja o nauce i wierze, „Znak” 291 (1978), s. 1139-1152.

Kołakowski L., Odwet sacrum w kulturze świeckiej, w: Czy diabet może być zbawiony i 27 innych kazań, Kraków 2006, s. 234-247.

Lem S., Dialogi, Warszawa 2010.

Lem S., Dzienniki gwiazdowe, Kraków 2001.

Lem S., Filozofia przypadku, t. II, Warszawa 1997.

Lem S., Golem XIV, Kraków 1999.

Lem S., Summa technologiae, Warszawa 2010.

Lem S., Wizja lokalna, Kraków-Wrocław 1983.

Lipowicz M., Czy „śmierć boga” jest „śmiercia społeczeństwa”? Próba połaczenia wybranych aspektów filozofii Fryderyka Nietzschego z filozofia i socjologia Georga Simmla, „Diametros” 37 (2013), s. 85-106.

Marks K., [Praca wyobcowana], www.nowakrytyka.pl/spip.php?article576 (29.04.2015).

McDowell J., Mind and World, Cambridge (MA) 1994. 
Mumford L., Mit maszyny, t. I, tłum. M. Szczubiałka, Warszawa 2012.

Nietzsche F., Tako rzecze Zaratustra. Ksiażka dla wszystkich $i$ dla nikogo, tłum. W. Berent, Poznań 2006.

Polak M., Urojone-nic. Postmodernistyczna metafizyka Stanislasa Bretona, Kraków 2014.

Robbins M., Be Yourself, Everyone Else is Already Taken: Transform Your Life with the Power of Authenticity, New York 2009.

Sartre J.-P., Byt i nicość. Zarys ontologii fenomenologicznej, tłum. J. Kiełbasa, P. Mróz i in., Kraków 2007.

Taylor Ch., A Secular Age, Cambridge (MA) 2007.

Warchała M., Autentyczność i nowoczesność. Figury autentyczności od Rousseau do Freuda, Kraków 2006.

Wittgenstein L., Dociekania filozoficzne, tłum. B. Wolniewicz, Warszawa 2000.

Wittgenstein L., O pewności, tłum. W. Sady, M. Sady, Warszawa 1993. 